\title{
Perceptions of forest experts on climate change and fire management in European Mediterranean forests
}

\author{
Yannis Raftoyannis ${ }^{(1)}$, Susanna Nocentini ${ }^{(2)}$, Enrico Marchi ${ }^{(2)}$, Rafael \\ Calama Sainz ${ }^{(3)}$, Carlos Garcia Guemes ${ }^{(4)}$, Ivan Pilas ${ }^{(5)}$, Sanja Peric ${ }^{(5)}$, \\ Joana Amaral Paulo ${ }^{(6)}$, Ana Cristina Moreira-Marcelino ${ }^{(7)}$, Maria Costa- \\ Ferreira $^{(8)}$, Erodotos Kakouris ${ }^{(9)}$, Marcus Lindner ${ }^{(10)}$
}

Climate change has already increased fire risk in Mediterranean forests. Adap tation options related to forest fires and climate change include measures related to fuel management, fire fighting and infrastructure, as well as public awareness. The importance of each of these measures was evaluated in six Mediterranean countries in a study initiated within the COST Action FP0703 "Expected Climate Change and Options for European Silviculture". A questionnaire survey was used to document the views of foresters and forest scientists. Country differences were observed and adaptation measures related to fire fighting efficiency and public awareness were valued as more important than fuel management. Results were discussed in the light of a critical review of adaptive fire management measures with special reference to European Mediterranean countries.

Keywords: Climate Change, Forest Fires, Survey, Perceptions, Adaptive Management, Mediterranean

\section{Introduction}

Climate change scenarios for Mediterranean Europe predict an increase in the number of years with high fire danger, an increase in the length of season with fire risk and an increase of extreme events during the fire season that could result in larger, more intense and more frequent fires (Moriondo et al. 2006, Giannakopoulos et al. 2009). Increasing drought events correlate with increased tree mortality that coincides with severe fire outbreaks (Sarris et al. 2011).
Simulations suggest a greater vulnerability of mountainous Mediterranean forests in dry areas regarding compositional alteration and flammability trends (Fyllas \& Troumbis 2009). Climate change has already contributed to the increased occurrence of large fires $(>1000 \mathrm{ha})$ that are responsible for most of the annual burned forest area, human casualties and severe damage to properties (Pausas 2004, Torre 2009, Moreira et al. 2011, Rodriguez-Silva 2011, Oliveira et al. 2012a). However, the increase in annual fire frequen-
(1) Department of Forestry, Technological Educational Institute of Lamia, G-36100 Karpenisi (Greece); (2) Department of Agricultural, Food and Forestry Systems, University of Florence, v. San Bonaventura 13, I-50145 Firenze (Italy); (3) Dip.to Selvicultura y Gestión Forestal, CIFOR-INIA, Ctra. A Coruña km 7.5, E-28040 Madrid (Spain); (4) Servicio Territorial de Medio Ambiente, Junta de Castilla y León, C/ Juan de Padilla s/n, E-09071 Burgos (Spain); (5) Croatian Forest Research Institute, 10450 Jastrebarsko (Croatia); (6) Instituto Superior de Agronomia, Tapada da Ajuda, 1349-017 Lisbon (Portugal); (7) Dept. de Protecção das Plantas, Estação Agronómica Nacional, INIAP, Av. da República, 2784-505 Nova Oeiras (Portugal); (8) Silviculture and Forest Products Unit, INIAV-INRB, 2780-159 Oeiras (Portugal); (9) Cyprus Department of Forests (Cyprus); (10) European Forest Institute, Torikatu 34, 80100 Joensuu (Finland)

\section{(a) Yannis Raftoyannis (rafto@teilam.gr)}

Received: Oct 11, 2012 - Accepted: Jul 30, 2013

Citation: Raftoyannis Y, Nocentini S, Marchi E, Calama Sainz R, Garcia Guemes C, Pilas I, Peric S, Amaral Paulo J, Moreira-Marcelino AC, Costa-Ferreira M, Kakouris E, Lindner M, 2014. Perceptions of forest experts on climate change and fire management in European Mediterranean forests. iForest 7: 33-41 [online 2013-10-14] URL: http://www.sisef.it/ iforest/contents/?id=ifor0817-006

Communicated by: Giorgio Matteucci cy and area burned can also be attributed to the increase in fuel amount and continuity due to rural depopulation and fuel build-up after farm abandonment (Pausas \& Fernández-Muñoz 2012).

Due to the frequency of occurrence and the magnitude of effects on the environment, health, economy, and security, forest fires have increasingly become a major subject of concern for decision makers, firefighters, researchers, and citizens in general (Miranda et al. 2009). Consequently, fire management is consuming a large amount of total investment in forestry. Greece, France, Italy, Portugal and Spain invest more than 2.5 billion euro each year in fire management (Birot \& Mavsar 2009). Most of this budget is dedicated to fire detection and suppression, and only a small amount for preventive actions (Torre 2009, Fernandes 2013). Due to this effort, suppression of low to medium intensity forest fires is nowadays usually successful but this is not the case in large and high intensity fires (Torre 2009, Castellnou et al. 2010, Castellnou 2011, Tedim et al. 2013).

Forest fires and climate change are important for the European forest policy as also reported in the Green Paper on Forest Protection (European Commission 2010). Among the sustainable forest management practices supporting forest protection there are several fire prevention measures (management of combustible material, establishment and maintenance of fire breaks, forest tracks, water supply points, appropriate choice of tree species, fixed forest fire monitoring facilities and communication equipment to prevent catastrophic fire spread).

A key issue for successful fire management under climate change is the adaptive capacity which depends not only on the available scientific and technical knowledge, but also on the social, economical, and political components associated with the implementation of the different adaptation options (Le Goff et al. 2005). Socio-economic factors determining adaptive capacity to climate change include economic development, technology and infrastructure, information, knowledge and skills, institutions, equity and social capital (McCarthy et al. 2001). There are considerable differences in adaptive capacity within Europe and it has been suggested that the higher weaknesses are to be found in the Mediterranean region, where the largest potential impacts are expected and consequently higher vulnerability to climate change (Lindner et al. 2010).

Despite a huge body of fire research in the Mediterranean Europe, knowledge on adaptive forest fire management under climate change is limited. Foresters and forest scientists play a critical role in the adaptive capacity of forests to risk factors such as climate change. Documenting the perspectives of 
forest experts could therefore provide useful insights into the state of knowledge and practice on climate adaptation within the forest sector (Williamson et al. 2005). Building on forest and fire managers' local knowledge could improve fire management options and reduce wildfire suppression costs and ecological disasters (Kalabokidis et al. 2008).
The main objective of COST Action FP0703 "Expected Climate Change and Options for European Silviculture" was to mobilize and integrate the existing scientific knowledge for European forest policymakers and managers who have to make decisions on adaptation to and mitigation of climate change. Within this framework, a group of scientists from the Action reviewed the rele- vant literature and designed a study based on questionnaires aiming to collect, analyze and discuss the existing perceptions of forest experts and practitioners from European Mediterranean countries on the issues of climate change and adaptive measures facing the increased risk of forest fires. The results of this study are presented in this paper with the aim to develop an understanding of the range

Tab. 1 - Kruskall-Wallis test for between-country differences in the ordinal median response for the importance of each adaptive measure (common rows) and group of measures (pooled row - in italic). Countries with the same letter in a row indicate non-significant differences at $\alpha=0.05$. (KW Prob): $p$-value after Kruskal-Wallis test.

\begin{tabular}{|c|c|c|c|c|c|c|c|c|c|}
\hline Group & Characteristics & All & Croatia & Cyprus & Greece & Italy & Portugal & Spain & $\begin{array}{l}\text { KW } \\
\text { Prob }\end{array}$ \\
\hline \multirow{8}{*}{$\begin{array}{l}\text { (1) Fire } \\
\text { fighting and } \\
\text { infrastructure }\end{array}$} & $\begin{array}{l}\text { Improvement of fire fighting co- } \\
\text { ordination }\end{array}$ & $4.3 \mathrm{~A}$ & $4.2 \mathrm{ab}$ & $4.4 \mathrm{ab}$ & $4.6 \mathrm{a}$ & $4.1 \mathrm{~b}$ & $4.1 \mathrm{ab}$ & $4.5 \mathrm{ab}$ & 0.0099 \\
\hline & $\begin{array}{l}\text { Increase of surveillance and } \\
\text { warning systems }\end{array}$ & 4.2 $\mathrm{AB}$ & $4.8 \mathrm{a}$ & $3.6 \mathrm{~b}$ & $4.2 \mathrm{~b}$ & $3.9 \mathrm{~b}$ & $4.1 \mathrm{~b}$ & $4.0 \mathrm{~b}$ & $<0.0001$ \\
\hline & $\begin{array}{l}\text { Improvement of education and } \\
\text { training of fire fighters }\end{array}$ & $4.1 \mathrm{~B}$ & $3.8 \mathrm{~b}$ & $4.2 \mathrm{ab}$ & $4.5 \mathrm{a}$ & $4.1 \mathrm{ab}$ & $3.9 \mathrm{~b}$ & $4.1 \mathrm{ab}$ & 0.0035 \\
\hline & Increase of water supply points & $3.7 \mathrm{C}$ & $3.5 \mathrm{~b}$ & $3.5 \mathrm{~b}$ & $4.4 \mathrm{a}$ & $3.9 \mathrm{ab}$ & $3.8 \mathrm{~b}$ & $3.5 \mathrm{~b}$ & $<0.0001$ \\
\hline & Increase of forest roads and paths & $3.6 \mathrm{C}$ & $3.9 \mathrm{a}$ & $3.4 \mathrm{ab}$ & $4.2 \mathrm{a}$ & $3.5 \mathrm{ab}$ & $3.6 \mathrm{ab}$ & $3.2 \mathrm{~b}$ & $<0.0001$ \\
\hline & $\begin{array}{l}\text { Increased use of decision support } \\
\text { systems }\end{array}$ & $3.5 \mathrm{C}$ & $3.1 \mathrm{~b}$ & $3.3 \mathrm{ab}$ & $3.9 \mathrm{a}$ & $3.3 \mathrm{~b}$ & $3.5 \mathrm{ab}$ & $3.8 \mathrm{a}$ & $<0.0001$ \\
\hline & Increase of fire fighting forces & $3.5 \mathrm{C}$ & $3.6 \mathrm{ab}$ & $3.7 \mathrm{ab}$ & $3.9 \mathrm{a}$ & $3.2 \mathrm{~b}$ & $3.3 \mathrm{ab}$ & $3.5 \mathrm{ab}$ & 0.0142 \\
\hline & $\begin{array}{l}\text { Fire figthing options } \\
\text { (pooled) }\end{array}$ & - & $3.9 B$ & $3.7 B$ & $4.2 \mathrm{~A}$ & $3.7 B$ & $3.8 B$ & $3.8 B$ & $<0.0001$ \\
\hline \multirow{7}{*}{$\begin{array}{l}\text { (2) Public } \\
\text { education and } \\
\text { management }\end{array}$} & $\begin{array}{l}\text { Improvement of public education } \\
\text { and awareness }\end{array}$ & $4.1 \mathrm{~A}$ & $4.2 \mathrm{a}$ & $4.1 \mathrm{a}$ & $3.9 \mathrm{a}$ & $4.1 \mathrm{a}$ & $3.9 \mathrm{a}$ & $4.3 \mathrm{a}$ & 0.0879 \\
\hline & $\begin{array}{l}\text { Improvement of patrolling and } \\
\text { law enforcement }\end{array}$ & $3.8 \mathrm{~B}$ & $4.2 \mathrm{a}$ & $4.1 \mathrm{ab}$ & $4.1 \mathrm{ab}$ & $3.6 \mathrm{ab}$ & $3.7 \mathrm{ab}$ & $3.5 \mathrm{~b}$ & 0.0020 \\
\hline & $\begin{array}{l}\text { Reduction of urban sprawling } \\
\text { into forests }\end{array}$ & $3.5 \mathrm{C}$ & $3.3 \mathrm{~b}$ & $3.1 \mathrm{~b}$ & $3.4 \mathrm{~b}$ & $3.4 \mathrm{~b}$ & $2.9 \mathrm{~b}$ & $4.3 \mathrm{a}$ & $<0.0001$ \\
\hline & $\begin{array}{l}\text { Reduction of human activities } \\
\text { in the wildland-urban interface }\end{array}$ & $2.8 \mathrm{D}$ & $3.2 \mathrm{a}$ & $2.9 \mathrm{ab}$ & $2.9 \mathrm{ab}$ & $2.4 \mathrm{~b}$ & $2.4 \mathrm{~b}$ & $2.7 \mathrm{ab}$ & 0.0011 \\
\hline & $\begin{array}{l}\text { Restriction of human activities } \\
\text { in forests }\end{array}$ & $2.7 \mathrm{D}$ & $3.4 \mathrm{a}$ & $2.8 \mathrm{abc}$ & $2.9 \mathrm{ab}$ & $2.1 \mathrm{c}$ & $2.7 \mathrm{~b}$ & $2.5 \mathrm{bc}$ & $<0.0001$ \\
\hline & Expansion of protected areas & $2.6 \mathrm{D}$ & $2.6 \mathrm{ab}$ & $3.1 \mathrm{ac}$ & $3.3 \mathrm{a}$ & $2.1 \mathrm{~b}$ & $2.5 \mathrm{ab}$ & $2.4 \mathrm{bc}$ & $<0.0001$ \\
\hline & $\begin{array}{l}\text { Public options } \\
\text { (pooled) }\end{array}$ & - & $3.5 \mathrm{~A}$ & $3.4 A B$ & $3.4 \mathrm{~A}$ & $3.0 \mathrm{C}$ & $3.0 B C$ & $3.3 A B C$ & $<0.0001$ \\
\hline \multirow{11}{*}{$\begin{array}{l}\text { (3) Fuel } \\
\text { management }\end{array}$} & Reduction of surface fuels & $3.7 \mathrm{~A}$ & $3.3 \mathrm{~b}$ & $3.2 \mathrm{~b}$ & $4.0 \mathrm{ab}$ & $3.7 \mathrm{ab}$ & $4.1 \mathrm{a}$ & $3.9 \mathrm{ab}$ & 0.0006 \\
\hline & Increased use of grazing & $3.3 \mathrm{~B}$ & $2.7 \mathrm{c}$ & $2.9 \mathrm{bc}$ & $3.5 \mathrm{ab}$ & $2.3 \mathrm{c}$ & $3.4 \mathrm{ab}$ & $4.0 \mathrm{a}$ & $<0.0001$ \\
\hline & $\begin{array}{l}\text { Improvement of reforestation } \\
\text { after fire }\end{array}$ & $3.3 \mathrm{~B}$ & $3.3 \mathrm{a}$ & $3.0 \mathrm{ab}$ & $3.8 \mathrm{a}$ & $2.2 \mathrm{~b}$ & $3.7 \mathrm{a}$ & $3.3 \mathrm{a}$ & $<0.0001$ \\
\hline & Increase of fire breaks & $3.2 \mathrm{~B}$ & $2.4 \mathrm{bc}$ & $3.6 \mathrm{ab}$ & $4.2 \mathrm{a}$ & $2.7 \mathrm{~b}$ & $3.9 \mathrm{a}$ & $2.9 \mathrm{bc}$ & $<0.0001$ \\
\hline & Reduction of stand density & $3.2 \mathrm{~B}$ & $3.2 \mathrm{ab}$ & $2.7 \mathrm{~b}$ & $3.1 \mathrm{ab}$ & $3.2 \mathrm{ab}$ & $2.9 \mathrm{ab}$ & $3.5 \mathrm{a}$ & 0.0072 \\
\hline & $\begin{array}{l}\text { Increase of plant cover with } \\
\text { species of reduced flammability }\end{array}$ & $3.1 \mathrm{~B}$ & $3.0 \mathrm{ab}$ & $2.7 \mathrm{ab}$ & $3.0 \mathrm{ab}$ & $2.8 \mathrm{~b}$ & $3.5 \mathrm{a}$ & $3.1 \mathrm{ab}$ & 0.0435 \\
\hline & $\begin{array}{l}\text { Increased use of prescribed } \\
\text { burning }\end{array}$ & $3 \mathrm{BC}$ & $2.4 \mathrm{~b}$ & $2.7 \mathrm{ab}$ & $3.2 \mathrm{ab}$ & $2.4 \mathrm{~b}$ & $3.5 \mathrm{a}$ & $3.5 \mathrm{a}$ & $<0.0001$ \\
\hline & Removal of standing dead trees & $2.8 \mathrm{CD}$ & $2.9 \mathrm{~b}$ & $2.1 \mathrm{~b}$ & $3.8 \mathrm{a}$ & $2.3 \mathrm{~b}$ & $2.9 \mathrm{~b}$ & $2.5 \mathrm{~b}$ & $<0.0001$ \\
\hline & $\begin{array}{l}\text { Transformation of coppiced } \\
\text { to high forests }\end{array}$ & $2.7 \mathrm{D}$ & $2.8 \mathrm{ab}$ & $1.7 \mathrm{c}$ & $2.5 \mathrm{abc}$ & $2.6 \mathrm{ab}$ & $2.4 \mathrm{bc}$ & $3.1 \mathrm{a}$ & $<0.0001$ \\
\hline & $\begin{array}{l}\text { Conversion of uneven aged } \\
\text { to even aged stands }\end{array}$ & $2.1 \mathrm{E}$ & $2.0 \mathrm{ab}$ & $1.5 \mathrm{~b}$ & $2.0 \mathrm{ab}$ & $2.5 \mathrm{a}$ & $2.1 \mathrm{ab}$ & $2.0 \mathrm{ab}$ & 0.0045 \\
\hline & $\begin{array}{l}\text { Fuel management options } \\
\text { (pooled) }\end{array}$ & - & $2.8 B$ & $2.6 B$ & $3.3 \mathrm{~A}$ & $2.7 B$ & $3.2 \mathrm{~A}$ & $3.2 \mathrm{~A}$ & $<0.0001$ \\
\hline
\end{tabular}


and diversity of opinions about climate change and adaptive measures related to forest fires, contributing to design possible measures to contribute to fire prevention, fighting and management.

\section{Material and methods}

A questionnaire survey was used to document the views of foresters and forest scientists. A list of 23 adaptation options was compiled from authors' professional experience and included measures related to fuel management, fire fighting and infrastructure as well as public awareness and management (Tab. 1). The questionnaire was distributed in 2011 by email, mail, online survey and personal contact. In total, three hundred forest experts (forest managers and forest scientists) from 6 Mediterranean countries answered the questionnaire: 53 from Croatia, 23 from Cyprus, 39 from Greece, 45 from Italy, 56 from Portugal and 84 from Spain. Respondents were asked to rate the importance of each of the 23 adaptation options of forest fire management in a changing climate, using a scale from 1 to 5 (1=not important; $2=$ not so important; $3=$ important; $4=$ very important; $5=$ the most important).

Given the non-normal and heteroscedastic behavior of ordinal data, a non-parametric Kruskall-Wallis test was applied to test the null hypothesis of homogeneity in the responses among different groups. The test was applied for assessing country differences in the response for each of the 23 individual adaptive measures, as well as for differences in each group of adaptive measures (fire fighting and infrastructure, public awareness and fuel management). Additionally, for each country, differences between the responses given for each group of adaptive measures were evaluated. Finally, the level of agreement or concordance between the country responses to the different measures within each of the three groups was evaluated by means of Kendall's Tau coefficient of concordance (Agresti 2010). Significant values of concordance will point to a pattern of agreement between countries in the ordinal ranking of the measures within a given group.

\section{Results}

The survey results indicated that forest experts considered fire fighting and infrastructure measures as more important than public awareness and fuel management, considering both pooled and separated countries (Tab. 2). However, there exist national differences in the relative importance of the general groups, with Portugal ranking fuel management measures higher than public awareness measures, and Spain and Greece showing no significant differences between these two groups of measures

A separate analysis of the differences

Tab. 2 - Kruskall-Wallis test for within-country differences in the ordinal median response between adaptive measures group within each country and all the countries pooled. Groups with the same letter in the same column indicate non-significant differences at an $\alpha=0.05$ level

\begin{tabular}{lccccccc}
\hline $\begin{array}{l}\text { Adaptation measures } \\
\text { group (pooled) }\end{array}$ & Croatia & Cyprus & Greece & Italy & Portugal & Spain & All \\
\hline Fire fighting options & $3.9 \mathrm{a}$ & $3.7 \mathrm{a}$ & $4.2 \mathrm{a}$ & $3.7 \mathrm{a}$ & $3.8 \mathrm{a}$ & $3.8 \mathrm{a}$ & $3.9 \mathrm{a}$ \\
Public options & $3.5 \mathrm{~b}$ & $3.4 \mathrm{~b}$ & $3.4 \mathrm{~b}$ & $3.0 \mathrm{~b}$ & $3.0 \mathrm{c}$ & $3.3 \mathrm{~b}$ & $3.2 \mathrm{~b}$ \\
Fuel management options & $2.8 \mathrm{c}$ & $2.6 \mathrm{c}$ & $3.3 \mathrm{~b}$ & $2.7 \mathrm{c}$ & $3.2 \mathrm{~b}$ & $3.2 \mathrm{~b}$ & $3.0 \mathrm{c}$ \\
\hline
\end{tabular}

Tab. 3 - Kendall's tau coefficient of concordance and associated p-value for the between countries agreement in the ranked response to the different adaptive measures included in each group.

\begin{tabular}{lcc}
\hline Adaptation measures group (pooled) & Kendall's tau & p-value \\
\hline Fire fighting options & 0.6876 & $<0.0001$ \\
Public options & 0.7615 & $<0.0001$ \\
Fuel management options & 0.4865 & 0.0002 \\
\hline
\end{tabular}

between countries on the pooled response to each group of measures (Tab. 1, rows indicating "pooled") show that firefighting and infrastructure options are ranked significantly higher in Greece than in the rest of the countries. Concerning fuel management options, relative importance is clearly separated among two national groups, with Greece, Portugal and Spain reaching higher values. Finally, significant differences in ranking response concerning public awareness measures are found between Croatia and Greece with respect to Italy and Portugal.

Considering each individual measure, overall, measures such as improvement of fire fighting coordination, increase of surveillance and warning systems and improvement of education and training of fire fighters were favored (Tab. 1). The improvement of fire fighting coordination was considered as the most important measure for Greece and very important for all other countries. The increase of surveillance and warning systems was rated as the most important option in Croatia and very important in all other countries. The improvement of education and training of fire fighters was rated as very important in all countries. The increase of water supply points was considered more important for Greece, Italy and Portugal. The increase of forest roads and paths was more important for Greece, Croatia and Portugal. Increased use of decision support systems was a very important option only for Greece and Spain. The increase of fire fighting forces was rated higher for Croatia, Cyprus and Greece.

Pooled data from all countries showed that improvement of public education and awareness and improvement of patrolling and law enforcement were considered as very important. Adaptation options such as the reduction of urban sprawling into forests, reduction of human activities in the wildland-urb- an interface, restriction of human activities in forests and expansion of protected areas were rated as important. The reduction of urban sprawling into forests was considered more important in Spain. The reduction of human activities in the wildland-urban interface was considered less important in Italy and Portugal. The restriction of human activities in forests was considered less important in Spain and Italy. The expansion of protected areas was more important for Greece and Cyprus.

Overall, the reduction of surface fuel loads was perceived the most important among the fuel management options. The use of grazing for fuel management was perceived to be of less importance for Italy. The improvement of reforestation after fire was considered as a very important measure in Greece and Portugal and less important in Italy. The increase of fire breaks was a high priority for Greece, Portugal and Cyprus. The reduction of stand density and the increase of plant cover with species of reduced flammability were perceived as important options by experts from all countries. Prescribed burning was not highly favored, especially in Croatia and Italy. The removal of standing dead trees was considered most as an acceptable practice in Greece. The transformation of coppice to high forests was not considered as a very important measure. The conversion of uneven-aged to even-aged stands was a low preference option for all countries.

Finally, a larger agreement between country rankings of individual measures was found in public awareness (Kendall's tau = $0.7615)$ and firefighting measures (0.6876) compared to fuel management options $(0.4865)$, though significant agreement is shown within all three groups (Tab. 3).

\section{Discussion}

Southern European countries differ sub- 
stantially regarding forest cover, morphology, fire regimes, forest management history and fire management systems. This variation probably influenced responses to the questionnaire, although from our data it is difficult to detect clear connections between the different factors. However, it is important to mention that while large betweencountry agreements were found when valuing and ranking the relative importance of the proposed adaptation options concerning fire-fighting and infrastructures (group 1) and people awareness (group 2), there are several significant between-country discrepancies related to the role of fuel management activities (group 3) in the general fireadaptive options framework.

\section{Fire fighting and infrastructure}

In all countries, forest experts and managers recognized the improvement of firefighting coordination as the most important adaptation measure in forest fire management (second most important in Croatia). The highest scores were mostly attributed to adaptation options related to fire suppression, with only slight differences among the different countries. This result contrasts the dominant opinion in fire management research that emerged during the last decades, i.e., that prevention activities are the most important component of forest fire management (e.g., Pinol et al. 2005, Marchi 2009a Fernandes et al. 2011, Moreira et al. 2011, Fernandes 2013). It has often been stated that the traditional focus on suppression led to an underestimation of other prevention activities such as forest management and information or education campaigns (Giovannini \& Marchi 2006) and therefore a new approach to fire management was advocated (Pinol et al. 2005, Xanthopoulos 2007, Bovio 2009, Marchi 2009a, Fernandes et al 2011, Moreira et al. 2011, Fernandes 2013) In fact, in many Mediterranean countries, even though fire suppression organization has been improved, the frequency of occurrence of large high intensity fires has been increasing recently (San-Miguel-Ayanz et al 2013). As fire suppression has failed to mitigate extreme fire seasons (e.g., Portugal 2003, 2005; Greece and Italy 2007), other fire management strategies should be considered. It is also evident that extreme climatic conditions contributed to the extension of fires into forests that were not considered to be fire-prone in the past (Koutsias et al. 2012).

The result of this survey thus highlights a contrasting approach to fire management between researchers and managers. One of the reasons of such a contrast may be that fire prevention is complex and its activities are often less obvious compared to fire suppression. During fire season, fire fighting means are immediately required, especially when infrastructures and people are threatened by fire. Moreover, successful fire suppression results are immediately perceived by citizens and policy makers, while fire prevention activities and their impacts are not easily and clearly recognizable by people and end-users in the short term. These issues consolidate the general public, policy makers and managers' opinion that fire suppression is more important than prevention. Another explanation could be that researchers have better access to information and experiences from other countries, where fire prevention measures have already longer traditions. Managers generally rely more on their own experiences and their education has always stressed the importance of fire suppression. However, the reasons for the striking difference in approaches should be better investigated and an increasing exchange of experiences should be encouraged.

According to our survey, the most important measures to be implemented are: improvement of fire fighting coordination; increase of surveillance and warning systems; and improvement of education and training of fire fighters. This would support the development of fire extinction strategies, such as: indirect attack by joint use of backfire (Miralles et al. 2010, Dupuy et al. 2011, Vega 2011) and chemical retardants (Martínez et al. 2009); new strategies to improve suppression based on the use of fire (Castellnou et al. 2010, Miralles et al. 2010); use of heavy machinery to define fire perimeters (Torre 2009); and fighting from the fire flanks during the night (Castellnou 2011). According to our survey, additional measures to improve fire extinction effectiveness should focus on the necessity to unify or at least improve the coordination among management, prevention and fire extinction services (Torre 2009).

In countries largely affected by fires and where fire management is a main priority in forest policies - Spain, Portugal and Greece the importance of preventive measures such as reduction of surface fuel loads, use of grazing or prescribed burning reaches values close to those for firefighting options. These countries share a stronger tradition of fire prevention and fire extinction practices, exhaustive networks of fire detection and infrastructures such as roads and fire breaks. This contrasts with the trend detected in Croatia, where non-Mediterranean moist temperate forests constitute a great part of the total forested area and fire is probably not considered as a great hazard. A particular case is that of Italy, which rates reduction of surface fuel and reduction of stand density at the same level of importance as Spain, Portugal and Greece, while it rates all other measures in the fuel management and preventive activities category as not important. Finally, in the case of Cyprus, though severely affected by forest fires, great efforts are actually being carried out in order to improve detection and extinction, thus probably affecting forester's opinion on the topic.

Technological development can improve surveillance and warning systems in fire fighting and shorten the fire detection and response times (Moreno 2005). However, complex terrain in mountain regions, such as found in many Mediterranean countries, poses a considerable constraint to forest infrastructure and technology which reduces adaptive capacities compared to more accessible lowland forests (Lindner et al. 2010). Nevertheless, this does not seem to be a constraint for the interviewed experts in this survey.

The survey results showed that lower importance is given to the improvement of infrastructure (water point, fire breaks, forest road and path) probably due to the fact that these structures have been improved over the last decades. This could depend on the fact that traditional fire fighting methods of direct attack with water and retardants using aerial means and land brigades has been proved efficient for most forest fire incidents but less successful in the confinement and extinction of very large fires (Torre 2009), such as the ones that can be connected to increased mega-fire risk in a climate change scenario.

As basic tools for aiding prevention, detection and extinction, fuel maps and fire risk indices are nowadays widely available (Velez 2009). Moreover, empirical growth and yield models recently incorporate the effect of thinning and management over fire risk indices (Castedo-Dorado et al. 2009, Crecente-Campo et al. 2009, Oliveira et al. 2012b). The development of specific decision support systems taking into account climate change may lead to better management and organization of firefighting resources, avoiding oversized suppression structures (Marchi et al. 2007, Rodriguez-Silva 2011). Climate change adaptation strategies consider as a priority fire prevention and planning using modern monitoring and modeling systems based on climate and land analysis (MATTM 2006, 2010). The relatively low importance attributed to decision support systems in our survey could depend on various factors such as scarce information on their real cost-effectiveness, scarce reliance on their ability to provide information useful for the "real" forestry world, as well as scarce information/education of forest technicians regarding these tools.

\section{Public awareness and management}

In the Mediterranean region, the majority of fires are human induced, mostly due to negligence and deliberate lighting. Consequently, it is becoming more and more evident that fire prevention policy should con- 
sider socioeconomic conditions and policies at different levels (Leone 1996, Scarascia-Mugnozza et al. 2000, Lovreglio et al. 2010). Questionnaire results confirm this view, showing that experts agree that working with a diversity of stakeholders on the effects of climate change on fire and forests is very important for developing support for and consistency in adaptation options. Local residents should be educated about how a warmer climate may increase fire frequency, how fuel reduction can protect property, while collaboration with public land managers will assist broader fuel management objectives. Encouraging communities to become involved with fire management will probably lead to greater sensitivity to risk and to less dangerous practices (Moreno 2005) Moreover, local knowledge could improve fire management options and reduce wildfire suppression costs (Kalabokidis et al. 2008). Other modern approaches like the fire-smart forest management approach (Hirsch et al. 2001) were not considered because they are not well established in Europe and probably not so suitable for the deeply transformed and populated southern European landscape.

New forest fire policy strategies should focus on the concept of integrated planning for active prevention and acting on topics such as education, involving of local communities in fire prevention, and law reinforcement. In this sense, Spanish integral plan 42 (García 2006) is an example of this approach. This plan covers the area of the 142 municipalities within the autonomous region of Castilla-León with larger impacts of fire. The Plan joins: (i) an active prevention program, focusing on environmental education, spreading information among farmers and livestock breeders of new methods for fire management; and valorization of new forest products and services; (ii) a dissuasion program: creation of a brigade for investigation of forest fires causes, reinforcement of prosecuting fire laws, subsides to forest fire good practices; and (iii) an indirect prevention program: to optimize and apply preventive silviculture, maintenance of defensible areas and infrastructures. Results from the first five years (2003-2007) of application have shown a substantial reduction in the number of fires in those involved municipalities if compared with the rest of the region.

Pressure for land development is high, especially in coastal forested areas of the $\mathrm{Me}$ diterranean countries where damage from forest fires is sometimes considered only a temporal source of degradation. In the last decades, in Mediterranean Europe, some rural and forested areas have experienced a population increase because of city dwellers moving into these areas, especially close to towns. New residents arriving from the urban areas have often brought with them a different set of social values and do not have the "rural and forest culture" necessary both to understand the importance of fuel control activities on their properties and to avoid carelessness or improper behavior causing fire ignition (Marchi 2009a). In the last years, in Italy, there has been an increase in prevention activity, mainly by a complex of actions aimed at reducing the forest fire number by containing or eliminating the types of human behavior which start fires (Giovannini \& Marchi 2005, Marchi 2009a). These activities have mostly been addressed to accidental/negligence fires reduction. $\mathrm{Ne}$ vertheless, many of these activities are discontinuous, thus reducing their effectiveness, and are usually limited to informative campaigns. This could explain the relatively low importance assigned by questionnaire respondents to the reduction of human activities in the wild-land/urban interface and to the restriction of human activities in forests. Thus, educational activities aimed at fostering the basic elements of a "forest culture" and at increasing individual awareness of environmental problems should be strongly supported (Marchi 2009a).

Fire risk should also be considered in regional/local land planning and legislation ought to be reinforced in relation to fire protection in the wild-land/urban interface. In Spain, fire prevention and extinction activities are being incorporated into forest and landscape management plans and regional laws require prevention plans even at a municipality scale (Ramírez et al. 2009, Velez 2009). Prevention planning should be extended also to private forest owners (e.g., in Andalusia specific planning is obligatory for private forests over 400 ha - Ruíz-Ortiz 2011).

In a warmer climate, human activities in forests (camping, hiking etc.) could be prolonged for longer periods and fire risk may be increased. Forest managers may seek to exclude or at least restrict some of these activities and come into conflict with public demand. Such measures could include law enforcement and intense patrolling especially at the urban-forest interface, restriction of human activities around forests especially during periods of particularly high fire danger and control of urban and suburban expansion into forested areas.

\section{Fuel management}

Many Mediterranean forests are not managed intensively and there are few active forest management options that can be employed to adapt forests to climate change. Instead, forest managers aim to maintain and enhance ecosystem resilience. The lack of economic activity in forestry and of systems for the remuneration of forest social and environmental services are constraining adaptive capacity in southern Europe, because adaptation would need to be implemented using policy incentives or societal activities with little support from forest owners and the forest sector (Lindner et al. 2010). During the previous decades, in most European Mediterranean countries, demographic flows and socio-economic changes have caused the abandonment of rural areas and the reduction of forest operations with subsequent fuel load accumulation (Moreira et al. 2011). In these countries, many forests are not regularly managed for wood production and the annual production of timber is decreasing due to the low market value of wood and generally high labor costs while only firewood harvesting from coppices remains relatively active (Corona \& Berti 2010). Moreover, landscape homogenization has increased the risk of fire spread into previously isolated forests and the propagation of large fires (Mazzoleni et al. 2009, Bovio 2011, Moreira et al. 2011, Pausas \& Fernández-Muñoz 2012, Fernandes 2013).

Reduction of stand density by thinning and treatment of surface fuels can reduce forest vulnerability to fire and increase resistance to drought and insect attack (Cantore \& Iovino 1989, Compostella \& Iovino 1999, Dale et al. 2001, Marchi 2009b). Nevertheless, our survey results did not rate fuel management as the most important group of options for reducing overall fire risk in the face of climate change. This result is surprising and will require a deeper analysis on the opinion of forest and fire managers. In particular, it will be necessary to understand why they usually do not rely on one of the main adaptive measures to fire risk which pertain to the forestry sector. Several aspects may affect forest and fire managers' opinion on this specific issue, such as: forest education programs not being up to date; an outdated approach of the wildfire sector targeted more to emergency rather than prevention management; easier and greater budget availability for fire extinction organization in comparison to forestry, due to the higher impact of the media on the former than the latter.

Biomass removal by regulated grazing is applied in Spain and Portugal while it is prohibited in the forests of Greece and Cyprus (Mosquera-Losada et al. 2006, Baiges et al. 2007, Mora et al. 2007, Bugalho et al. 2011). It is interesting to note that this measure is considered important in Spain and Portugal but also in Greece, where it is prohibited. The main advantages of grazing are related with the valorization of forested areas due to animal products, but the inability of animals to eat woody debris requires an initial and periodical mechanical treatment (Vega 2011). In Spain, grazing as a fire preventive measure is subsidized and there are initiatives to promote the activity, like the creation of shepherds' schools (Dopazo et al. 2009, Robles-Cruz et al. 2011). 
The use of prescribed burning as a method for fire prevention has been increasingly applied in Portugal and France since the early 80's and in Spain since the 90's (Vega \& Velez 2000, Lázaro \& Montiel 2010 Rodriguez-Silva 2011). Experimental trials with prescribed burning have been carried out in Italy, but there is no practical application of this preventive technique (Ascoli et al. 2012, Ascoli \& Bovio 2013), while in Greece and Cyprus, prescribed burning is prohibited. Prescribed fire is a fast and cheap method for reducing dead and live biomass and from an ecological perspective surrogates the natural impact of low to medium intensity fires (Fernández et al. 2008, Castellnou 2011). This measure did not rate very high in the survey, probably because risks and cost-efficiency have to be considered when using prescribed burning, and specific know-how is required to control the fire front (Lindner et al. 2008). Prescribed fire can scorch the crowns of live trees, which may increase stress or tree mortality (Graham et al. 2004). Narrow suited climate conditions for prescribed burning application that can even become narrower by increasing dry periods, possible negative effects over soil characteristics and complex forest-urban interface have been pointed out as limitations to the wide application of prescribed burning (Vega 2011).

Another topic of discussion affecting between-country discrepancies in the group of fuel management adaptive options is related with the research and knowledge trans fer to the sector. As an example it is interesting to observe that grazing control (Dopazo et al. 2009) or prescribed burning practices (Fernandes \& Botelho 2003, 2004, Fernández et al. 2008) show a larger relative importance in Spain or Portugal. These measures have been a topic of major scientific research in these countries and exhaustive demonstrations over large experimental areas have been carried out (Vega \& Velez 2000). This result focuses to the importance of: (i) developing national and joint transnational research experiences and projects focusing on fuel management; and (ii) developing adequate transfer mechanisms to spread the results of these experiences to the wide forest community.

A slightly better rating was attributed by respondents to firebreaks which aim to disrupt the fuel continuity and provide access to fire fighters (Serrada et al. 2008, Velez 2009). Nowadays, classical linear firebreaks without vegetation are being complemented with or substituted by defensible areas where fuel loads are modified by applying heavy thinning, pruning and understory release with a gradient of intensity (Velasco 2009) When choosing the location of these areas, spatial decision criteria should be taken into consideration, such as effectiveness for ex- tinction forces in occurrence of large fires, defense urban areas, existing landscape discontinuities and maximum expected time for extinction teams to arrive at any point within the forest (Ruíz-Ortiz 2011). Mechanical treatments are traditionally used to maintain firebreaks, although the current economic crisis has affected this practice and other cheaper and probably more effective alternatives have been suggested such as prescribed burning and controlled grazing (Lázaro \& Montiel 2010, Robles-Cruz et al. 2011).

Thinning can favor the establishment and growth of a dense understory composed by heliophilous shrubs and evergreen oaks that should be controlled (Serrada et al. 2008, Velez 2009, Vega 2011). Lowering tree density may exacerbate fire behavior because more solar radiation to the forest floor can desiccate dead and live fuels (Agee \& Skinner 2005). Nevertheless, respondents still rated silvicultural methods for stand density reduction as important.

Coppice forests are particularly vulnerable to fire due to their biomass structure and fuel management should focus on thinning and transformation to high forests (Ciancio \& Nocentini 2004). Fuel management should also consider the canopy structure as it affects crown fire behavior; it has been shown that even-aged pine stands give higher intensity crown fires than uneven-aged stands (Mitsopoulos \& Dimitrakopoulos 2007).

The increase in fire risk due to climate change may require a rethinking on tree species composition, especially in pine and eucalypt Mediterranean forests (Leone \& Lovreglio 2004). In countries with extended pine plantations there is a management strategy aiming to favor the local broadleaf species (mainly deciduous oaks), i.e., forest stands more resilient and less susceptible to fire (Nocentini 2000, 2001, La Mela Veca 2009, Nocentini \& Puletti 2009). Landscapelevel management strategies can also help to reduce susceptibility to forest fires such as planting less flammable barriers to reduce the risks of large fires (Lindner et al. 2008). However, this practice has its limitations because of the strong competitive advantages of pines over most oak species, especially in a drier climate (Barčić et al. 2006, Dubravac et al. 2006, Fyllas et al. 2008).

The main limitations to fuel treatments are the high costs and the difficult terrain, typical in many Mediterranean forests. However, the increasing demand for forest biomass can make such operations cost effective (Tolosana 2009). Fuel management techniques should advance through knowledge of plant species and ecosystems and should contemplate, apart from fire prevention, the conservation of biodiversity, carbon fixation and the fight against desertification (Pilliod et al. 2006, Lindner et al. 2008).
Alongside the damage they cause, wildfires can also be regarded as an opportunity to plan and establish less flammable and more resilient forests and landscapes in recently burned areas (Moreira et al. 2012). However, post-fire management should respect natural regeneration, improve ecosystem resilience and take into account risks related to climate change in the long-term ecosystem recovery (Raftoyannis \& Spanos 2005, Spanos et al. 2005, Baldini et al. 2007). Furthermore, post-fire management should be adaptive integrating results of previous interventions to iteratively improve and accommodate change by learning from the outcomes of experimented practices (Moreira et al. 2012).

\section{Conclusions}

The perceptions of foresters and forest scientists from European Mediterranean countries were investigated on the issues of climate change and adaptive measures facing the increased risk of forest fires. The results showed that increasing fire fighting efficiency and public awareness were considered more important by the respondents than fuel management. Moreover, different priorities in adaptive fire management options were evident among countries. Nevertheless, the questionnaire results indicate that there is a need for integrated fire management.

The result of this survey highlighted a contrasting approach to fire management between managers and researchers. The main reason of such a discrepancy is likely due to the high visibility of fire suppression relative to fire prevention strategies. However, even fire suppression has been unable to mitigate the extent of burned areas during extreme fire seasons, suggesting the need of an integrated approach to fire management.

Understanding the reasons of such contrasting approach between researchers and managers requires specific studies and an increasing exchange of experiences. In particular, the dissemination of scientific research results to fire managers should be improved, possibly in each country language. An improved communication between research and management is critical for a large-scale application of an integrated approach to fire management.

Mediterranean countries have always been living with forest fires but nowadays scenarios of climate change indicate that forest fires are likely to further increase in number, size and frequency. The need to adapt national fire management systems might not be adequate if cross border cooperation between Mediterranean countries is missing. This paper reveals that such cooperation, exchange of ideas, knowledge, experiences and network development is feasible and very helpful to support forest managers in their response to climate change. 


\section{Acknowledgments}

This paper was initiated and implemented within the COST Action FP0703 "Expected Climate Change and Options for European Silviculture". We thank COST (European Cooperation in Science and Technology) for providing funds for the Action. The Italian contribution was partially carried out within the project PRIN 2009 "in_FLAMING" funded by the Italian Ministry of Education, University and Research. We also thank two anonymous referees for their comments and Mary Crnkovic-Pilas for language editing.

\section{References}

Agee JK, Skinner CN (2005). Basic principles of forest fuel reduction treatments. Forest Ecology and Management 211: 83-96. - doi: 10.1016/j.foreco.2005.01.034

Agresti A (2010). Analysis of ordinal categorical data $\left(2^{\text {nd }}\right.$ edn). Wiley Series in Probability and Statistics, John Wiley and Sons Inc., NJ, USA.

Ascoli D, Bovio G (2013). Prescribed burning in Italy: issues, advances and challenges. iForest 6 : 79-89. - doi: 10.3832/ifor0803-006

Ascoli D, Catalanotti AE, Valese E, Cabiddu S, Delogu G, Driussi M, Esposito A, Leone V, Lovreglio R, Marchi E, Mazzoleni S, Rutigliano FA, Strumia S, Bovio G (2012). Prescribed burning experiences in Italy: an integrated approach to prevent forest fires. Forest@ 9: 20-38. [in Italian with English Abstract] - doi: 10.3832/ efor0686-009

Baiges T, Casals P, Taüll M (2007). Gestión silvopastoral en Catalunya: de sistema productivo a herramienta de conservación. Cuadernos SECF 22: 11-16.

Baldini S, Certini G, Di Fulvio F, Giovannini G, Marchi E (2007). Environmental impact of postfire logging in a Maritime pine stand in Tuscany (Central Italy). In: Proceedings of the " 4 th International Wildland fire Conference", 13-17 May 2007, Seville, Spain.

Barčić D, Hršak V, Španjol Z (2006). The ameliorative effects of pine cultures on forest sites on the island of Rab in Southwest Croatia. Forest Ecology and Management 237: 39-46. - doi: 10.1016/j.foreco.2006.09.065

Birot Y, Mavsar R (2009). Wildfires Impact in 3D: Environment, Economy, Society. In: "Living with wildfires: what science can tell us. A contribution to the science-policy dialogue" (Birot Y ed). EFI Discussion Paper no. 15, European Forest Institute, Joensuu, Finland, pp. 33-37.

Bovio G (2009). Incendi boschivi: attualità e prospettive. In: "Atti del Terzo Congresso Nazionale di Selvicoltura". Taormina (ME - Italy), 16-19 October 2008. Accademia Italiana di Scienze Forestali, Firenze, pp. 323-326. [in Italian]

Bovio G (2011). Forest fires and systemic silviculture. L'Italia Forestale e Montana 66: 239-243. doi: 10.4129/ifm.2011.3.09

Bugalho M, Lecomte X, Gonçalves M, Caldeira M, Branco M (2011). Establishing grazing and grazing-excluded patches increases plant and invertebrate diversity in a Mediterranean oak woodland. Forest Ecology and Management 261: 2133-2139. - doi: 10.1016/j.foreco.2011.03.009 Cantore V, Iovino F (1989). Effetti dei diradamenti sull'umidità del suolo in popolamenti di douglasia della Catena Costiera (Calabria). Annali Ist. Sper. Selvicoltura, vol. XX.

Castedo-Dorado F, Crecente-Campo F, ÁlvarezÁlvarez P, Barrio-Anta M (2009). Development of a stand density management diagram for radiata pine stands including assessment of stand stability. Forestry 82: 1-16. - doi: 10.1093/ forestry/cpm032

Castellnou M (2011). Experiencia adquirida en los grandes incendios de Cataluña. In: "Lecciones aprendidas en los grandes incendios forestales" (Rodriguez-Silva F ed). SECF-Universidad de Córdoba-MIMARM, Spain, pp. 147-160. Castellnou M, Kraus D, Miralles M, Delegou G (2010). Suppression fire use in learning organizations. In: "Towards integrated fire management: outcomes of the European project FIREPARADOX" (Sande Silva J, Rego F, Fernandes P, Rigolot E eds). European Forest Institute, Porvoo, Finland, pp. 189-201.

Ciancio O, Nocentini S (2004). Il bosco ceduo. Selvicoltura, assestamento, gestione. Accademia Italiana di Scienze Forestali, Firenze, Italy, pp. 721. [in Italian]

Compostella G, Iovino F (1999). Studio dell'umidità del suolo in relazione ai diradamenti in popolamenti di pino laricio. L'Italia Forestale e Montana 6: 308-323. [in Italian]

Corona P, Berti S (2010). Selvicoltura: produzioni forestali, certificazione e filiera legno. Italian Journal of Forest and Mountain Environments 2: 149-155. [in Italian] - doi: 10.4129/IFM.2010. 2.07

Crecente-Campo F, Pommerening A, RodríguezSoalleiro R (2009). Impacts of thinning on structure, growth and risk of crown fire in a Pinus sylvestris L. plantation in northern Spain. Forest Ecology and Management 257: 1945-1954. doi: 10.1016/j.foreco.2009.02.009

Dale VH, Joyce LA, McNulty S, Neilson RP, Ayres MP, Flannigan MD, Hanson PJ, Irland LC, Lugo AE, Peterson CJ, Simberloff D, Swanson FJ, Stocks BJ, Wotton BM (2001). Climate change and forest disturbances. BioScience 51: 723-734. - doi: 10.1641/0006-3568(2001)051 [0723:CCAFD]2.0.CO;2

Dopazo C, Robles Ab, Ruiz R, San Miguel A (2009). Efecto del pastoreo en el mantenimiento de cortafuegos en la Comunidad Valenciana. In: "Actas V $V^{\mathbf{0}}$ Congreso Forestal Español". Avila (Spain), Sep 2009. [online] URL: http://www.congresoforestal.es/index.php?men=93

Dubravac T, Barčić D, Španjol Z, Vrbek B, Roth V, Dekanić S (2006). Natural reforestation of Aleppo pine (Pinus halepensis Mill.) stands after forest fire. Forest Ecology and Management 234: 206-216. - doi: 10.1016/j.foreco.2006.08.325

Dupuy JL, Linn R, Konovalov V, Pimont F, Vega JA, Jiménez E (2011). Exploring three dimensional coupled fire-atmosphere interactions downwind of wind-driven surface fires and their influence on backfires using the HIGRAD-
FIRETEC model. International Journal of Wildland Fire 20: 734-750. - doi: 10.1071/WF10035

European Commission (2010). Green paper on forest protection and information in the EU: preparing forests for climate change. 1.3.2010 COM(2010)66 final, Brussels, Belgium. [online] URL: http://eur-lex.europa.eu/LexUriServ/LexUriServ.do?uri=COM:2010:0066:FIN:EN:PDF Fernandes P, Botelho H (2003). A review of prescribed burning effectiveness in fire hazard reduction. International Journal of Wildland Fire 12: 117-128. - doi: 10.1071/WF02042

Fernandes P, Botelho H (2004). Analysis of the prescribed burning practice in the pine forest of northwestern Portugal. Journal of Environmental Management 70: 15-26. - doi: 10.1016/j.jenvman.2003.10.001

Fernandes PM (2013). Fire-smart management of forest landscapes in the Mediterranean basin under global change. Landscape and Urban Planning 110: 175-182 - doi: 10.1016/j.landurbplan. 2012.10.014

Fernandes PM, Rego FC, Rigolot E (2011). The FIRE PARADOX project: Towards sciencebased fire management in Europe. Forest Ecology and Management 261: 2177-2178. - doi: 10.1016/j.foreco.2010.12.024

Fernández C, Vega JA, Fonturbel T, Jiménez E, Pérez-Gorostiaga P (2008). Effects of wildfire, salvage logging and slash manipulation on Pinus pinaster Ait. recruitment in Orense (NW Spain). Forest Ecology and Management 255: 12941304. - doi: 10.1016/j.foreco.2007.10.034

Fyllas NM, Troumbis AY (2009). Simulating vegetation shifts in north-eastern Mediterranean mountain forests under climatic change scenarios. Global Ecology and Biogeography 18:6477. - doi: 10.1111/j.1466-8238.2008.00419.x Fyllas NM, Dimitrakopoulos PG, Troumbis AY (2008). Regeneration dynamics of a mixed Mediterranean pine forest in the absence of fire. Forest Ecology and Management 256:15521559. - doi: 10.1016/j.foreco.2008.06.046 García J (2006). PLAN 42. Un programa integral para la prevención de incendios forestales. Consejería de Medio Ambiente, Junta de Castilla y León, Spain, pp. 108. [in Spanish]

Giannakopoulos C, Le Sager P, Bindi M, Moriondo M, Kostopoulou E, Goodess CM (2009). Climatic changes and associated impacts in the Mediterranean resulting from a $2{ }^{\circ} \mathrm{C}$ global warming. Global and Planetary Change 68:209224. - doi: 10.1016/j.gloplacha.2009.06.001

Giovannini G, Marchi E (2005). La prevenzione degli incendi boschivi: il ruolo dell'informazione e dell'educazione ambientale. In: "Foreste Ricerca Cultura, scritti in onore di Orazio Ciancio" (Corona P, Iovino F, Maetzke F, Marchetti M, Menguzzato G, Nocentini S, Portoghesi L eds). Accademia Italiana di Scienze Forestali, Firenze, Italy, pp. 237-250. [in Italian] Giovannini G, Marchi E (2006). Il forestale nelle attività di Educazione Ambientale. In: Atti del Convegno ' $L$ 'opera di prevenzione degli incendi boschivi e l'educazione ambientale". Vallombrosa (FI - Italy), 22-23 June 2006. Osservatorio 
Foreste e Ambiente, I Quaderni, vol. 5, pp. 171180. [in Italian]

Graham RT, McCaffrey S, Jain TB (2004). Science basis for changing forest structure to modify wildfire behavior and severity. General Technical Report RMRS-GTR-120, USDA Forest Service, Ogden, Utah, USA.

Hirsch K, Kafka V, Tymstra C, McAlpine R, Hawkes B, Stegehuis H, Quintilio S, Gauthier S, Peck K (2001). Fire-smart forest management: a pragmatic approach to sustainable forest management in fire-dominated ecosystems. Forestry Chronicle 77: 357-363.

Kalabokidis K, Iosifides T, Henderson M, Morehouse B (2008). Wildfire policy and use of science in the context of a socio-ecological system on the Aegean Archipelago. Environmental Science and Policy 11: 408-421. - doi: 10.1016/ j.envsci.2008.01.006

Koutsias N, Arianoutsou M, Kallimanis AS, Mallinis G, Halley JM, Dimopoulos P (2012). Where did the fires burn in Peloponnisos, Greece the summer of 2007? Evidence for a synergy of fuel and weather. Agricultural and Forest Meteorology 156: 41-53. - doi: 10.1016/j.agrformet.2011.12.006

La Mela Veca DS (2009). Ecologia e selvicoltura dei boschi artificiali di conifere dei Monti Sicani (Sicilia). In "Atti del Terzo Congresso Nazionale di Selvicoltura". Taormina (ME - Italy), 16-19 October 2008. Accademia Italiana di Scienze Forestali, Firenze, Italy, pp. 205-212. [in Italian] Le Goff H, Leduc A, Bergeron Y, Flannigan M (2005). The adaptive capacity of forest management to changing fire regimes in the boreal forest of Quebec. The Forestry Chronicle 81: 582-592.

Leone V, Lovreglio R (2004). Le cause degli incendi dolosi in Italia. In: "Dossier - Incendi e gestione forestale" (Bovio G ed). Alberi e Territorio 1 (6): 31-35. [in Italian]

Leone V (1996). Aspetti sociologici nella fenomenologia degli incendi boschivi. In: "Il bosco e l'uomo" (Ciancio O ed). Accademia Italiana di Scienze Forestali, Firenze, Italy, pp. 309-327. [in Italian]

Lindner M, Garcia-Gonzalo J, Kolström M, Green T, Reguera R, Maroschek M, Seidl R, Lexer MJ, Netherer S, Schopf A, Kremer A, Delzon S, Barbati A, Marchetti M, Corona P (2008). Impacts of climate change on European forests and options for adaptation. Report for DG Agriculture, European Forest Institute, Joensuu, Finland, pp. 172.

Lindner M, Maroschek M, Netherer S, Kremer A, Barbati A, Garcia-Gonzalo J, Seidl R, Delzon S, Corona P, Kolström M, Lexer M J, Marchetti M (2010). Climate change impacts, adaptive capacity, and vulnerability of European forest ecosystems. Forest Ecology and Management 259: 698709. - doi: 10.1016/j.foreco.2009.09.023

Lovreglio R, Leone V, Giaquinto P, Notarnicola A (2010). Wildfire cause analysis: four case-studies in southern Italy. iForest 3: 8-15. - doi: 10.3832/ ifor0521-003

Lázaro A, Montiel C (2010). Overview of prescribed burning policies and practices in Europe and other countries. In: "Towards integrated fire management: outcomes of the European project FIREPARADOX" (Sande Silva J, Rego F, Fernandes $\mathrm{P}$, Rigolot $\mathrm{E}$ eds). European Forest Institute, Porvoo, Finland, pp. 137-150.

Marchi E (2009a). Approccio integrato alla difesa dagli incendi boschivi. In: "Atti del Terzo Congresso Nazionale di Selvicoltura". Taormina (ME - Italy) 16-19 October 2008. Accademia Italiana di Scienze Forestali, Firenze, Italy, pp 327-334. [in Italian]

Marchi E (2009b). Comportamento ed effetti degli incendi boschivi in rapporto alla gestione del combustibile. In: Atti del Convegno "La gestione della difesa dagli incendi boschivi". Vallombrosa (FI - Italy) 19-20 June 2009. Osservatorio Foreste e Ambiente, I Quaderni, vol. 9, pp. 3542. [in Italian]

Marchi E, Tesi E, Monterselli Brachetti N, Bonora L, Conese C, Romani M (2007). Forest fire prevention: an integrate risk analysis to improve management and planning actions. In: Proceedings of the Congress "Bottlenecks, solutions, and priorities in the context of functions of forest resources: the $150^{\text {th }}$ anniversary of forestry education in Turkey". Harbiye (Istanbul - Turkey) 17-19 October 2007, pp. 517-526.

Martínez E, Aguirre F, Gómez R (2009). Nuevos Medios y Nuevas Técnicas en la lucha contra los incendios forestales.In: "Actas $\mathrm{V}^{\mathrm{o}}$ Congreso Forestal Español". Avila (Spain), Sep 2009. [online] URL: http://www.congresoforestal.es/index.php?men $=93$

MATTM (2006). Verso la strategia nazionale per la biodiversità. Esiti del tavolo tecnico Cambiamenti climatici e biodiversità. Studio della mitigazione e proposte per l'adattamento. Italian Ministry of Environment, Rome, Italy. [in Italian] [online] URL: http://www.minambiente.it/ menu/menu attivita/Progetto Verso la Strateg ia_Nazionale_p.html

MATTM (2010). Strategia nazionale per la biodiversità. Italian Ministry of Environment, Rome, Italy. [in Italian] [online] URL: http://www.minambiente.it/export/sites/default/a rchivio/allegati/biodiversita/Strategia_Nazionale per la Biodiversita.pdf

Mazzoleni S, Migliozzi A, Ricotta C, Bajocco S, Di Pasquale G, Saracino A (2009). Boschi di neoformazione e nuovi scenari di propagazione d'incendio. In: "Atti del Terzo Congresso Nazionale di Selvicoltura". Taormina (ME - Italy), 1619 October 2008. Accademia Italiana di Scienze Forestali, Firenze, Italy, pp. 372-377. [in Italian] McCarthy JJ, Canziani OF, Leary NA, Dokken DJ, White KSE (2001). Climate change 2001: impacts, adaptation, and vulnerability. Cambridge University Press, UK.

Miralles M, Kraus D, Molina D, Loureiro C, Delegou G, Ribet N, Vilalta O (2010). Improving suppession fire capacity. In: "Towards integrated fire management: outcomes of the European project FIREPARADOX" (Sande Silva J, Rego F, Fernandes P, Rigolot E eds). European Forest Institute, Porvoo, Finland, pp. 203-215.

Miranda AI, Marchi E, Ferretti M, Millán MM
(2009). Forest fires and air quality issues in southern Europe. In: "Developments in Environmental Science" (Krupa SV, Bytnerowicz A, Arbaugh MJ, Riebau AR, Andersen $\mathrm{C}$ eds). Wild Land Fires and Air Pollution, Vol. 8, Elsevier, The Netherlands, pp. 209-231.

Mitsopoulos ID, Dimitrakopoulos AP (2007). Canopy fuel characteristics and potential crown fire behavior in Aleppo pine (Pinus halepensis Mill.) forests. Annals of Forest Science 64:287299. - doi: 10.1051/forest:2007006

Mora MJ, Fernández B, Bedia J (2007). Utilización por ganado caprino del sotobosque arbustivo de una parcela mixta de prado-eucaliptal en Cantabria. Cuadernos SECF 22: 95-100. [in Spanish]

Moreira F, Viedma O, Arianoutsou M, Curt T, Koutsias N, Rigolot E, Barbati A, Corona P, Vaz P, Xanthopoulos G, Mouillot F, Bilgili E (2011). Landscape-wildfire interactions in southern Europe: Implications for landscape management. Journal of Environmental Management 92: 2389-2402. - doi: 10.1016/j.jenvman.2011.06. 028

Moreira F, Arianoustou M, Vallejo VR, De las Heras J, Corona P, Xanthopoulos G, Fernandes P, Papageorgiou K (2012). Setting the scene for post-fire management. In: "Post-fire management and restoration of southern European forests" (Moreira F, Arianoustou M, Corona P, De Las Heras J eds). Springer, Dordrecht, The Netherlands, pp. 1-20.

Moreno JM (2005). A preliminary assessment of the impacts in Spain due to the effects of climate change. Spanish Ministry of Environment, Madrid, Spain.

Moriondo M, Good P, Durao R, Bindi M, Giannakopoulos C, Corte-Real J (2006). Potential impact of climate change on fire risk in the Mediterranean area. Climate Research 31: 85-95. doi: $10.3354 / \mathrm{cr} 031085$

Mosquera-Losada MR, Pinto-Tobalina M, Rigueiro-Rodríguez A (2006). The herbaceous component in temperate silvopastoral systems. In: "Silvopastoralism and silvopastoral sytems" (Mosquera-Losada MR, Mcadam J, RigueiroRodríguez A eds). CABI, Wallingford, USA, pp. 93-100.

Nocentini S, Puletti N (2009). La rinaturalizzazione dei rimboschimenti. Prova sperimentale su un popolamento di pino nero e laricio. In: "Atti del Terzo Congresso Nazionale di Selvicoltura per il miglioramento e la conservazione dei boschi italiani". Taormina (ME - Italy) 16-19 October 2008. Accademia Italiana di Scienze Forestali, Firenze, Italy, pp. 217-227. [in Italian] doi: $10.4129 / \mathrm{CNS} 2008.028$

Nocentini S (2000). La rinaturalizzazione dei sistemi forestali: aspetti concettuali. L'Italia Forestale e Montana 55: 211-218. [in Italian]

Nocentini S (2001). La rinaturalizzazione come strumento di recupero dei sistemi forestali semplificati nell'Italia Meridionale. L'Italia Forestale e Montana 56: 344-351. [in Italian]

Oliveira S, Oehler F, San-Miguel-Ayanz J, Camia A, Pereira JMC (2012a). Modeling spatial pat- 
terns of fire occurrence in Mediterranean Europe using multiple regression and Random forest. Forest Ecology and Management 275: 117-129. doi: 10.1016/j.foreco.2012.03.003

Oliveira SLJ, Pereira JMC, Carreiras JMB (2012b). Fire frequency analysis in Portugal (1975-2005), using Landsat-based burnt area maps. International Journal of Wildland Fire 21: 48-60. - doi: 10.1071/WF10131

Pausas JG, Fernández-Muñoz S (2012). Fire regime changes in the Western Mediterranean Basin: from fuel-limited to drought-driven fire regime. Climatic Change 110:215-226. - doi: 10.1007/s10584-011-0060-6

Pausas JG (2004). Changes in fire and climate in the eastern Iberian Peninsula (Mediterranean Basin). Climate Change 63: 337-350. - doi: 10.1023/B:CLIM.0000018508.94901.9c

Pilliod DS, Bull EL, Hayes JL, Wales BC (2006) Wildlife and invertebrate response to fuel reduction treatments in dry coniferous forests of the western United States: a synthesis. General Technical Report RMRS-GTR-173, USDA Forest Service, Ogden, Utah, USA.

Pinol J, Beven K, Viegas DX (2005). Modelling the effect of fire-exclusion and prescribed fire on wildfire size in Mediterranean ecosystems. Ecological Modelling 183: 397-409. - doi: 10.1016/ j.ecolmodel.2004.09.001

Raftoyannis Y, Spanos I (2005). Evaluation of log and branch barriers as post-fire rehabilitation treatments in a Mediterranean pine forest in Greece. International Journal of Wildland Fire 14:183-188. - doi: 10.1071/WF04031

Ramírez J, Blanco J, Lahoz JM, Pérez E, Saz F, Ferrer M, Clavero MA, Bardají M, López Del Río R (2009). Planes comarcales de prevención de incendios forestales en las zonas de alto riesgo (ZAR) de Aragón: unejemplo de planificación integral a nivel operativo en el entorno de las tecnologías de la información geoespacial. In: “Actas V V $^{\mathrm{o}}$ Congreso Forestal Español”. Avila
(Spain) Sep 2009. [in Spanish] [online] URL: http://www.congresoforestal.es/index.php? men=93

Robles-Cruz AB, González Rebollar JL, RuizMirazo J (2011). Ganadería extensiva y silvicultura preventiva: algo más que una mirada alpasado. Ambienta 97. [online] URL: http://www. revistaambienta.es/WebAmbienta/marm/Dinamicas/secciones/articulos/Silvicultura.htm

Rodriguez-Silva F (2011). Lecciones aprendidas en los grandes incendios forestales. SECF-Universidad de Córdoba-MIMARM, Spain, pp. 287. [in Spanish]

Ruíz-Ortiz J (2011). Selvicultura preventiva y grandes incendios forestales. In: "Lecciones aprendidas en los grandes incendios forestales" (Rodriguez-Silva F ed). SECF-Universidad de Córdoba-MIMARM, Spain, pp. 56-75. [in Spanish]

San-Miguel-Ayanz J, Moreno JM, Camia A (2013). Analysis of large fires in European Mediterranean landscapes: lessons learned and perspectives. Forest Ecology and Management 294:11-22. - doi: 10.1016/j.foreco.2012.10.050

Sarris D, Christodoulakis D, Körner C (2011). Impact of recent climatic change on growth of low elevation eastern Mediterranean forest trees. Climatic Change 106: 203-223. - doi: 10.1007/ s10584-010-9901-y

Scarascia-Mugnozza G, Oswald H, Piussi P, Radoglou K (2000). Forests of the Mediterranean region: gaps in knowledge and research needs. Forest Ecology and Management 132: 97-109. doi: 10.1016/S0378-1127(00)00383-2

Serrada R, Aroca MJ, Roig S (2008). Selvicultura preventiva de incendios. In: "Compendio de Selvicultura Aplicada en España" (Serrada R, Montero G, Reque JA eds). FUCOVASA, Madrid, Spain, pp: 949-979.[in Spanish]

Spanos I, Raftoyannis Y, Goudelis G, Xanthopoulou E, Samara T, Tsiontsis A (2005). Effects of postfire logging on soil and vegetation reco- very in a Pinus halepensis Mill. forest of Greece. Plant and Soil 278: 171-179. - doi: 10.1007/ s11104-005-0807-9

Tedim F, Remelgado R, Borges C, Carvalho S, Martins J (2013). Exploring the occurrence of mega-fires in Portugal. Forest Ecology and Management 294: 86-96. - doi: 10.1016/j.foreco. 2012.07.031

Tolosana E (2009). Manual Técnico para el aprovechamiento y elaboración de biomasa forestal. Mundi-prensa, Madrid, Spain, pp. 348. [in Spanish]

Torre M (2009). La situación actual del problema de los incendios forestales en España. Cuadernos SECF 31: 179-195. [in Spanish]

Vega JA, Velez R (2000). Actas de la Reunión sobre Quemas Prescritas. Cuadernos SECF 9, Sociedad Española Ciencias Forestales, Pontevedra, Spain, pp. 205. [in Spanish]

Vega JA (2011). Gestión de combustibles para prevención de Incendios Forestales. In: "Actas Jornada Técnica Prevención Inteligente de Incendios Forestales en Europa". Proyecto EUFIRESMART, Madrid, Spain. [in Spanish]

Velasco L (2009). Planificación de redes de áreas cortafuegos. In: "La defensa contra incendios forestales: fudnamentos y experiencias" (Velez R ed). McGraw-Hill, Madrid, Spain, chapt. 14.2. [in Spanish].

Velez R (2009). La defensa contra incendios forestales: fundamentos y experiencias $\left(2^{\text {nd }} \mathrm{edn}\right) . \mathrm{Mc}-$ Graw-Hilll, Madrid, Spain, pp. 841. [in Spanish] Williamson TB, Parkins JR, McFarlane BL (2005). Perceptions of climate change risk to forest ecosystems and forest-based communities. Forestry Chronicle 81: 710-716. - doi: 10.5558/ tfc81710-5

Xanthopoulos G (2007). Forest fire policy scenarios as a key element affecting the occurrence and characteristics of fire disasters. In: Proceedings of the " $4^{\text {th }}$ International Wildland fire Conference". Seville (Spain) 13-17 May 2007. 